\section{Pentavalent Organoantimony} Compounds as Mild $N$-Arylating Agents for Amines: Cu-Mediated Ullmann-Type $\mathrm{N}$-Arylation with Tetraarylantimony(V)

\section{Acetates}

\author{
Weiwei QIN, ${ }^{a, b}$ Naoki KaKUSAWA, ${ }^{a}$ Yichen Wu, ${ }^{a}$ \\ Shuji YASUIKE, ${ }^{a, b}$ and Jyoji KURITA*, ${ }^{*}$
}

${ }^{a}$ Faculty of Pharmaceutical Sciences, Hokuriku University; and ${ }^{b}$ Organization for Frontier Research in Pharmaceutical Sciences, Hokuriku University; Kanagawa-machi, Kanazawa 920-1181, Japan.

Received December 6, 2008; accepted January 24, 2009; published online January 26, 2009

Simple and mild $\mathrm{Cu}$-mediated arylation of various amines by use of tetraarylantimony acetate $\left(\mathrm{Ar}_{4} \mathrm{SbOAc}\right)$ is described. The Ullmann-type condensation of $\mathrm{Ar}_{4}$ SbOAc with aliphatic and electron rich aromatic amines proceeded efficiently in the presence of copper(II) acetate. The arylation can be carried out under aerobic conditions without care of exogenous oxygen. This simple procedure exceeds the conventional Ullmann condensation which often requires harsh reaction conditions.

Key words tetraarylantimony(V) acetate; $N$-arylation; Ullmann condensation; copper(II) acetate; aerobic reaction

The aryl-nitrogen bond can be found in a wide range of biologically active compounds such as bradykinin (BK) receptor antagonist martinellic acid ${ }^{1)}$ and opioid receptor agonist CJ-15161. ${ }^{2)}$ Thus, it is desirable to develop simple and efficient methods for aryl-nitrogen bond formation. Among them, research on transition metal-catalyzed $\mathrm{C}-\mathrm{N}$ bond formation has flourished recently. For example, remarkable progress in bulky and electron rich phosphine ligands has enabled Pd- and Ni-catalyzed cross-couplings of amines and alcohols with aryl halides and sulfonates. ${ }^{3,4)}$ These transition metal-catalyzed reactions have been recognized as one of the most reliable methods for $\mathrm{C}-\mathrm{N}$ bond formation. ${ }^{5-8)}$ Direct $\mathrm{C}-\mathrm{H}$ functionalization to form $\mathrm{C}-\mathrm{N}$ bonds has also been another convenient entry for $\mathrm{C}-\mathrm{N}$ cross-coupling using transition metal catalysts. ${ }^{9,10}$ However, these elaborated catalysts and phosphine ligands often tend to be sensitive to air oxidation and hydrolysis by moisture. These problems make the traditional Ullmann condensation attractive in large and industrial scale applications employing low price, non-toxic, and air-stable $\mathrm{Cu}$ reagents. ${ }^{11-14)}$

Because traditional $\mathrm{Cu}$-mediated Ullmann condensation has been conducted and limited by harsh reaction conditions, ${ }^{15)}$ many improvements in Ullmann-type $\mathrm{C}-\mathrm{N}$ bond formation have recently been made. For example, aryl halides employed as aryl donors in the traditional Ullmann condensation were replaced with highly reactive transmetallating agents such as organo-boron, ${ }^{13,14,16-19)}$-silicon, ${ }^{20)}$-stannane, ${ }^{19,21)}$-lead, ${ }^{14,22)}$ and -bismuth compounds. ${ }^{14,23-25)}$

In the course of our studies on organoantimony ( $\mathrm{Sb}$ ) compounds as synthetic reagents, we have recently demonstrated that $\mathrm{Sb}$ (III) compounds were efficient transmetallating agents for transition metal-catalyzed cross-coupling reactions. ${ }^{26,27)}$ We also reported that $\mathrm{Sb}(\mathrm{V})$ compounds work as useful pseudo-halides in Pd-catalyzed cross-coupling reactions. ${ }^{28)}$ These results stimulated us to employ them in $\mathrm{Cu}$-mediated arylation of amines.

As for Sb-mediated $\mathrm{N}$ - and $\mathrm{O}$-arylation of amines and alcohols, triphenylantimony ortho-phenylenedioxides and triphenylstibane have been reported to function as aryl donors. ${ }^{29,30)}$ However, the reactions are not so efficient, in that they must be carried out using amines or alcohols as solvents at high temperature. Thus, we focused on highly reactive $\mathrm{Sb}(\mathrm{V})$ compounds as $\mathrm{Cu}$-mediated $\mathrm{N}$-arylating agents. $^{31,32)}$

To search for effective organoantimony compounds in $\mathrm{Cu}$ mediated $N$-arylation of amines, we first investigated the reaction of various $\mathrm{Sb}(\mathrm{V})$ compounds $(\mathbf{1}-\mathbf{5})$ with $p$-toluidine (6a) in the presence of $\mathrm{Cu}(\mathrm{OAc})_{2}$ under the conditions shown in Table 1. The reaction of $\mathrm{Ph}_{5} \mathrm{Sb}$ (1) with $\mathbf{6 a}$ resulted in the expected $N$-phenylation to afford $N$-phenyl- $p$-toluidine (7a) in $80 \%$ yield. However a considerable amount of homo-coupling product (8: $27 \%$ yield) was formed as a side product. Whereas treatment of 6a with $\mathrm{Ph}_{4} \mathrm{SbOAc}(2)$ gave $7 \mathbf{a}$ in $84 \%$ yield and no noticeable formation of $\mathbf{8}$ was observed. ${ }^{33}$ ) When bromostiboranes $(\mathbf{3}, \mathbf{4})$ were employed in the present reaction, di(p-tolyl)diazene (9) was formed as a major product. The reaction by use of diacetate $\mathrm{Ph}_{3} \mathrm{Sb}(\mathrm{OAc})_{2}(\mathbf{5})$ instead of 2 was ineffective and afforded 7a in $6 \%$ yield. It has been well documented that the $\mathrm{Cu}$-mediated $\mathrm{N}$ - and $\mathrm{O}$-arylation with arylboronic acids could be achieved effectively in the presence of an oxidizing agent or under aerobic conditions. ${ }^{13,14)}$ However, the reaction under oxygen atmosphere did not improve the yield of $7 \mathbf{a}(67 \%)$. Similar reaction under argon atmosphere also gave $7 \mathbf{a}$ in $70 \%$ yield.

We next searched for suitable $\mathrm{Cu}$ reagent, and the results are summarized in Table 2, entries $1-6$. The divalent $\mathrm{Cu}$ reagent $\mathrm{Cu}(\mathrm{OBz})_{2}$ also promoted the $N$-arylation, but the yield of $7 \mathbf{a}$ was unsatisfactory. It is noteworthy that monovalent $\mathrm{CuOAc}$ and $\mathrm{Cu}(\mathrm{I})$ thiophene-2-carboxylate (CuTC) were effective, giving rise to $\mathbf{7 a}$ in acceptable yields. Addition of $\mathrm{Cu}$ powder also promoted the $N$-arylation, but stoichiometric amount of copper reagent is essential. We next attempted catalytic reaction by use of $0.3 \mathrm{eq} \mathrm{Cu}(\mathrm{OAc})_{2}$ and found that the reaction afforded $7 \mathrm{a}$ in $69 \%$ yield after $24 \mathrm{~h}$ at $40{ }^{\circ} \mathrm{C}$. This result implies that the $\mathrm{N}$-arylation proceeds under the catalytic

Table 1. Reaction of Organoantimony(V) Compounds $(\mathbf{1}-\mathbf{5})$ with $\mathbf{6 a}^{a)}$

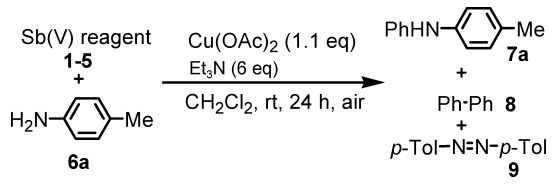

\begin{tabular}{clccc}
\hline \hline & & \multicolumn{3}{c}{ Yield $/ \%^{b)}$} \\
\cline { 3 - 5 } Entry & $\mathrm{Sb}(\mathrm{V})$ reagent & $\mathbf{7 a}$ & $\mathbf{8}$ & $\mathbf{9}$ \\
\cline { 3 - 5 } & & 80 & 27 & 0 \\
1 & $\mathbf{1}: \mathrm{Ph}_{5} \mathrm{Sb}$ & $84(88)^{c)}$ & 0 & 0 \\
2 & $\mathbf{2}: \mathrm{Ph}_{4} \mathrm{SbOAc}$ & 7 & 0 & 62 \\
3 & $\mathbf{3}: \mathrm{Ph}_{4} \mathrm{SbBr}$ & $<0.5$ & 0 & 71 \\
4 & $\mathbf{4}: \mathrm{Ph}_{3} \mathrm{SbBr}$ & 6 & 0 & 6 \\
5 & $\mathbf{5 :} \mathrm{Ph}_{3} \mathrm{Sb}(\mathrm{OAc})_{2}$ & & & \\
\hline
\end{tabular}

a) Reaction conditions: $\mathbf{1}-\mathbf{5}(0.75 \mathrm{mmol}), \mathbf{6 a}(0.5 \mathrm{mmol}), \mathrm{Cu}(\mathrm{OAc})_{2}(0.55 \mathrm{mmol})$ and $\mathrm{Et}_{3} \mathrm{~N}(3 \mathrm{mmol})$ in $\mathrm{CH}_{2} \mathrm{Cl}_{2}(5 \mathrm{ml})$. b) Isolated yield. c) $\mathrm{GC}$ yield. 
Table 2. Reaction of $\mathbf{2}$ with 6a Using Various Cu-Reagents and Bases ${ }^{a)}$

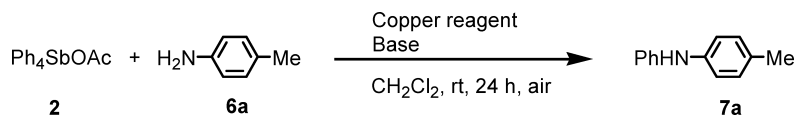

\begin{tabular}{|c|c|c|c|c|c|c|c|}
\hline Entry & $\mathrm{Cu}$ reagent & Base & $7 \mathbf{a} / \%^{b)}$ & Entry & $\mathrm{Cu}$ reagent & Base & $7 \mathbf{a} / \%{ }^{b)}$ \\
\hline 1 & $\mathrm{Cu}(\mathrm{OAc})_{2}$ & $\mathrm{Et}_{3} \mathrm{~N}$ & 88 & 7 & $\mathrm{Cu}(\mathrm{OAc})_{2}$ & None & 19 \\
\hline 2 & $\mathrm{Cu}(\mathrm{OBz})_{2}$ & & 66 & 8 & & $(i-\mathrm{Pr})_{2} \mathrm{NH}$ & 75 \\
\hline 3 & $\mathrm{CuOAc}$ & & 74 & 9 & & Pyridine & 9 \\
\hline 4 & $\mathrm{CuTC}^{c)}$ & & 65 & 10 & & $\mathrm{DBU}^{e)}$ & 36 \\
\hline 5 & $\mathrm{Cu}$ powder & & 56 & 11 & & $\mathrm{TMED}^{f}$ & $\mathrm{ND}^{d)}$ \\
\hline 6 & None & & $\mathrm{ND}^{d)}$ & 12 & & $\left.2,2^{\prime}-\mathrm{bpy}^{\mathrm{g}}\right)$ & $\mathrm{ND}^{d)}$ \\
\hline
\end{tabular}

a) Reaction conditions: 2 (0.75 mmol), 6a $(0.5 \mathrm{mmol}), \mathrm{Cu}(\mathrm{OAc})_{2}(0.55 \mathrm{mmol})$, and base $(3 \mathrm{mmol})$ in $\left.\mathrm{CH}_{2} \mathrm{Cl}_{2}(5 \mathrm{ml}) . \quad b\right) \mathrm{GC}$ yield. $\left.\quad c\right)$ Copper(I) thiophene-2-carboxylate. d) Not detected. e) 1,8-Diazabicyclo[5.4.0]undec-7-ene. f) $N, N, N^{\prime}, N^{\prime}$-Tetramethylethylenediamine. $g$ ) 2,2'-Bipyridyl.

Table 3. Ullmann-Type $N$-Phenylation of Various Amines ${ }^{a)}$

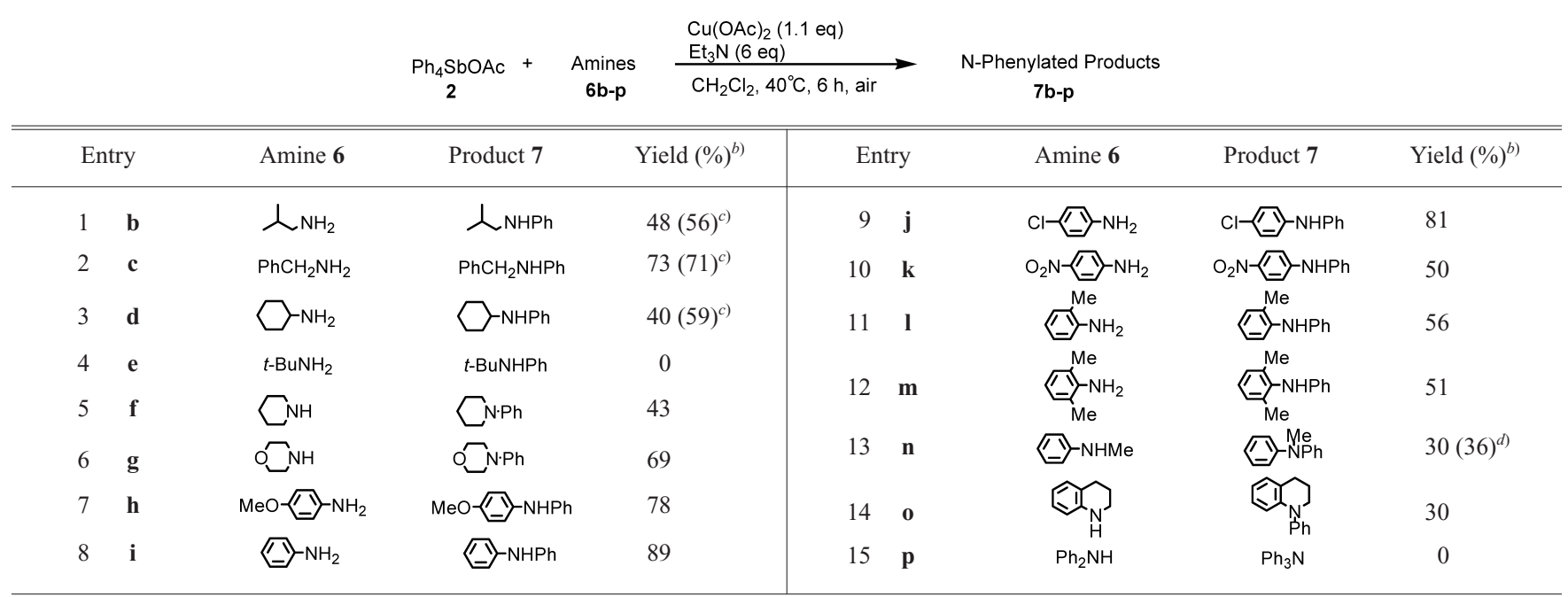

a) $2(0.75 \mathrm{mmol})$, amines $6(0.5 \mathrm{mmol}), \mathrm{Cu}(\mathrm{OAc})_{2}(0.55 \mathrm{mmol}), \mathrm{Et}_{3} \mathrm{~N}(3 \mathrm{mmol})$ in $\mathrm{CH}_{2} \mathrm{Cl}_{2}(5 \mathrm{ml})$. b ) Isolated yields. c) The reaction was carried out by using 0.5 eq of $\mathrm{Cu}(\mathrm{OAc})_{2}$. d) Reaction time: $24 \mathrm{~h}$.

condition, however, the reaction requires longer reaction time and higher temperature to achieve satisfactory result. Thus, we decided to use 1.1 eq of $\mathrm{Cu}(\mathrm{OAc})_{2}$ in the following experiments.

We next examined the effect of bases and the results are shown in Table 2, entries 7-12. The reaction proceeded without base, but the yield was lower than that in the presence of triethylamine (TEA). The reaction needs excess TEA (6.0 eq) for homogeneous reaction. When 3.0 eq of TEA was used in the present reaction, a part of $\mathrm{Cu}(\mathrm{OAc})_{2}$ remains undissolved and the yield of $7 \mathbf{a}$ decreased to $76 \%$ after $48 \mathrm{~h}$ (GC yield). Addition of di(isopropyl)amine promoted $\mathrm{N}$ phenylation, while that of pyridine and DBU gave unsatisfactory results. It should be noted that bidentate amines such as TMEDA and 2,2'-bipyridyl completely suppressed the $N$-arylation. Search for a suitable solvent revealed that dichloromethane $(88 \%$, GC yield) was the optimal solvent; toluene $(58 \%)$, 1,4-dioxane (25\%), and acetonitrile ( $83 \%)$ led to inferior results. Consequently, the best result was obtained when the reaction was carried out by using $\mathrm{Cu}(\mathrm{OAc})_{2}$ as a copper reagent (1.1 eq), TEA (6.0 eq) as a base, and dichloromethane as a solvent under atmospheric air. When a mixture of 2 and $\mathbf{6 a}$ was heated at $40{ }^{\circ} \mathrm{C}$ for $6 \mathrm{~h}$ under the above optimal conditions, 7a was isolated in good yield $(84 \%)$. Thus, we performed the subsequent reactions at

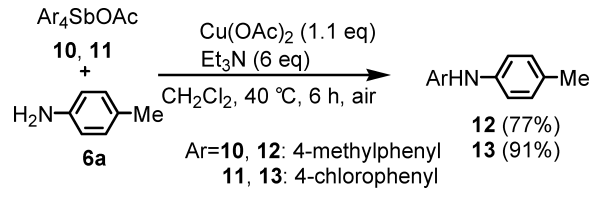

Chart 1. Reaction of Tetraarylantimony Acetate $(\mathbf{1 0}, \mathbf{1 1})$ with $\mathbf{6 a}$

$40{ }^{\circ} \mathrm{C}$. In the reactions of tetrakis(4-methylphenyl)- (10) and tetrakis(4-chlorophenyl)antimony acetate (11) with 6a, the expected $N$-arylated products, bis(4-methylphenyl)amine (12) and (4-chlorophenyl)(4-methylphenyl)amine (13) were isolated in good yields, respectively (Chart 1). ${ }^{34)}$

Having the established reaction conditions, various amines $(\mathbf{6 b}-\mathbf{p})$ were reacted with $\mathbf{2}$ (Table 3 ). Primary aliphatic amines gave the corresponding $N$-arylated product $(\mathbf{7 b}-\mathbf{d})$ in moderate yields which could be improved by carrying out the reactions with 0.5 eq of $\mathrm{Cu}(\mathrm{OAc})_{2}$. The results imply that these aliphatic amines were easily oxidized to form azo-compounds with excess $\mathrm{Cu}(\mathrm{OAc})_{2} \cdot{ }^{35)}$ In the case of aromatic amines, a marked $p$-substituent effect was observed. The aromatic amines with an electron-donating $p$-methoxy group gave superior result to that with an electron-withdrawing $p$ nitro group. Sterically hindered ortho-substituted aniline derivatives $(\mathbf{6 1}, \mathbf{m})$ and secondary amines $(\mathbf{6} \mathbf{f}, \mathbf{g}, \mathbf{n}, \mathbf{0})$ also gave the corresponding $N$-arylated products in moderate yields ex- 


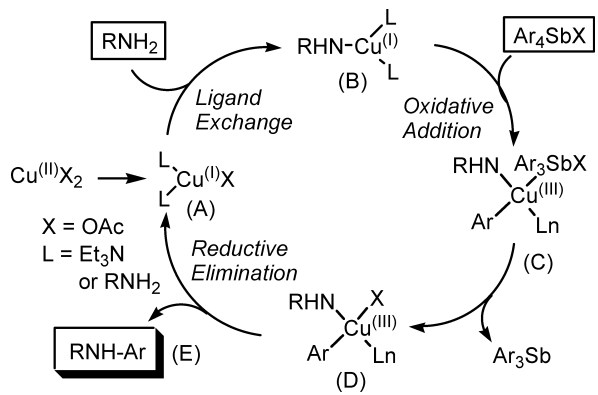

Chart 2. Possible Mechanism

cept for $t$-butyl- (6e) and diphenylamines (6p). The fact that no formation of triphenylamine from $\mathbf{6 p}$ is in good accordance with the observation that only mono-phenylated product of amines was formed in the present reaction.

Exact mechanism of this Sb-mediated $N$-arylation is unclear at present. We considered that a similar mechanism for diaryliodonium salts by Lockhart ${ }^{36)}$ and for lead(VI ${ }^{22)}$ and bismuth $(\mathrm{V})^{23)}$ compounds by Barton et al. could be applicable to our Sb-mediated $N$-arylation (Chart 2).

The first step of the reaction would be the generation of $\mathrm{Cu}$ (I) species (A) by reduction of $\mathrm{Cu}(\mathrm{OAc})_{2}$ with amine or excess TEA. The intermediate $\mathbf{A}$ thus formed reacts with amine to give $\mathrm{Cu}(\mathrm{I}) \mathrm{L}_{2} \mathrm{NHR}$ (B). Oxidative addition of $\mathrm{Ar}_{4} \mathrm{SbOAc}$ to $\mathbf{B}$ affords $\mathrm{Cu}(\mathrm{III})$ intermediate (C) which leads to $\mathrm{Cu}$ (III) complex (D) accompanied by elimination of $\mathrm{Ar}_{3} \mathrm{Sb}$. This intermediate (D) successively undergoes reductive elimination to give the final product $(\mathbf{E})$ with regeneration of the $\mathrm{Cu}(\mathrm{I})$ species (A). As noted above, $\mathrm{Ar}_{3} \mathrm{Sb}$ was formed during the course of this reaction, however, the formation of $\mathrm{Ar}_{3} \mathrm{Sb}$ was not detected by GC analysis of the reaction mixture. This result would be explained that $\mathrm{Ar}_{3} \mathrm{Sb}$ is easily oxidized to $\mathrm{Ar}_{3} \mathrm{SbO}$ or $\mathrm{Ar}_{3} \mathrm{Sb}(\mathrm{OAc})_{2}$ by air or excess $\mathrm{Cu}(\mathrm{OAc})_{2}$ in the reaction mixture. A similar reaction was observed in the $N$-arylation of amines ${ }^{23)}$ and hydrazones ${ }^{25}$ by use of $\mathrm{Ar}_{3} \mathrm{Bi}$ and $\mathrm{Cu}(\mathrm{OAc})_{2}$.

In conclusion, we disclosed that hypervalent $\mathrm{Ar}_{4} \mathrm{SbOAc}$ is a new $N$-arylating agent which can be used under mild conditions without special care of exogenous oxygen. We have also recently found that a similar $N$-arylation took place when a mixture of $\mathrm{Ar}_{3} \mathrm{Sb}$ and amine (6) was heated with large excess $\left(2.5-5\right.$ eq) of $\mathrm{Cu}(\mathrm{OAc})_{2}$ in acetonitrile, however, the reaction requires a longer reaction time $(6-24 \mathrm{~h})$ at higher temperature $\left(60-70^{\circ} \mathrm{C}\right)$. The details including its reaction mechanism and further application of this simple and mild $N$-arylation will be discussed in due course.

Acknowledgements This work was supported by a Grants-in-Aid for Scientific Research (C) from Japan Society for the Promotion of Science (JK), The "Academic Frontier" Project for Private Universities from the Ministry of Education, Culture, Sports, Science and Technology of Japan (WQ and SY), and Specific Research Fund of Hokuriku University (NK).

\footnotetext{
References and Notes

1) Ma D., Xia C., Jiang J., Zhang J., Tang W., J. Org. Chem., 68, 442451 (2003).

2) Ghosh A., Sieser J. E., Caron S., Couturier M., Dupont-Gaudet K., Girardin M., J. Org. Chem., 71, 1258-1261 (2006).

3) Hartwig J. F., Angew. Chem. Int. Ed., 37, 2046-2067 (1998).

4) Yang B. H., Buchwald S. L., J. Organomet. Chem., 576, 125-126
}

(1999).

5) Kataoka N., Shelby Q., Stambuli J. P., Hartwig J. F., J. Org. Chem., 67, 5553 - 5566 (2002)

6) Anderson K. W., Mendez-Perez M., Priego J., Buchwald S. L., J. Org. Chem., 68, 9563-9573 (2003).

7) Zim D., Buchwald S. L., Org. Lett., 5, 2413-2415 (2003).

8) Strieter E. R., Buchwald S. L., Angew. Chem. Int. Ed., 45, 925-928 (2006).

9) Au S.-M., Huang J.-S., Che C.-M., Yu W.-Y., J. Org. Chem., 65, 7858 - 7864 (2000).

10) Tsang W. C. P., Zheng N., Buchwald S. L., J. Am. Chem. Soc., 127, $14560-14561$ (2005).

11) Ullmann F., Ber. Dtsch. Chem. Ges., 36, 2382-2384 (1903).

12) Beletskaya I. P., Cheprakov A. V., Coordination Chem. Rev., 248, 2337-2364 (2004)

13) Ley S. V., Thomas A. W., Angew. Chem. Int. Ed., 42, 5400-5449 (2003).

14) Finet J.-P., Fedrov A. Y., Combes S., Boyer G., Current Org. Chem., 6, $597-626$ (2002).

15) Yamamoto T., Kurata Y., Can. J. Chem., 61, 86-91 (1983).

16) Lam P. Y. S., Clark C. G., Saubern S., Adams J., Winters M. P., Chan D. M. T., Combs A., Tetrahedron Lett., 39, 2941-2944 (1998).

17) Chan D. M. T., Monaco K. L., Wang R.-P., Winters M. P., Tetrahedron Lett., 39, 2933-2936 (1998).

18) Jacobsen M. F., Knudsen M. M., Gothelf K. V., J. Org. Chem., 71, 9183-9190 (2006).

19) Zhang Z., Yu Y., Libeskind L. S., Org. Lett., 10, 3005-3008 (2008).

20) Lam P. Y. S., Deudon S., Averill K. M., Li R., He M. Y., Deshong P., Clark P., J. Am. Chem. Soc., 122, 7600-7601 (2000).

21) Lam P. Y. S., Vincent G., Bonne D., Clark C. G., Tetrahedron Lett., 43, 3091-3094 (2002).

22) Barton D. H. R., Donnelly D. M. X., Finet J.-P., Guiry P. J., J. Chem. Soc., Perkin Trans. I, 1991, 2095-2102 (1991).

23) Barton D. H. R., Finet J.-P., Khamsi J., Tetrahedron Lett., 28, $887-$ 890 (1987).

24) Arnauld T., Barton D. H. R., Doris E., Tetrahedron, 53, 4137-4144 (1997).

25) Starkov P., Zemskov I., Sillard R., Tšubrik O., Mäeorg U., Tetrahedron Lett., 48, 1155-1157 (2007).

26) Kakusawa N., Tobiyasu Y., Yasuike S., Yamaguchi K., Seki H., Kurita J., J. Organomet. Chem., 691, 2953-2968 (2006).

27) Kakusawa N., Kurita J., Chem. Pharm. Bull., 56, 1502-1504 (2008).

28) Qin W., Yasuike S., Kakusawa N., Sugawara Y., Kawahata M., Yamaguchi K., Kurita J., J. Organomet. Chem., 693, 109-116 (2008).

29) Stolyarova T. E., Shavyrin A. S., Federov A. Y., Russ. Chem. Bull. Int. Ed., 52, 1736-1739 (2003).

30) Dodonov V. A., Gushchin A. V., Tolstova O. G., Organomet. Chem. U.S.S.R., 5, 274-277 (1992).

31) Yamamoto H., Oshima K., "Main Group Metals in Organic Synthesis," Wiley-VCH, Weinheim, 2004

32) Akiba K.-y., "Chemistry of Hypervalent Compounds," Wiley-VCH, New York, 1999.

33) Typical procedure: To a solution of $\mathbf{2}(0.75 \mathrm{mmol}), \mathbf{6 a}(0.5 \mathrm{mmol})$, and TEA $(3.0 \mathrm{mmol})$ in $\mathrm{CH}_{2} \mathrm{Cl}_{2}(5 \mathrm{ml})$ was added $\mathrm{Cu}(\mathrm{OAc})_{2}(0.55 \mathrm{mmol})$, and the mixture was stirred for $6 \mathrm{~h}$ at $40{ }^{\circ} \mathrm{C}$ (bath temperature). The mixture was diluted with $\mathrm{CH}_{2} \mathrm{Cl}_{2}(50 \mathrm{ml})$ and $\mathrm{NH}_{3}$ aq. $(1.5 \mathrm{~mol} / \mathrm{l}$, $50 \mathrm{ml}$ ) and then stirred for $30 \mathrm{~min}$. The organic layer was separated, washed with brine and dried over anhydrous $\mathrm{MgSO}_{4}$. After removal of the solvent in vacuo, the residue was separated by $\mathrm{SiO}_{2}$ column chromatography (hexane : $\mathrm{CH}_{2} \mathrm{Cl}_{2}=3: 1$ ) to give $7 \mathbf{a}(77 \mathrm{mg}, 84 \%$ yield).

34) The tetraarylantimony acetates $(\mathbf{2}, \mathbf{1 0}, \mathbf{1 1})$ were prepared by disproportination reaction on heating $1: 1$ mixture of $\mathrm{Ar}_{5} \mathrm{Sb}$ and $\mathrm{Ar}_{3} \mathrm{Sb}(\mathrm{OAc})_{2}$ in toluene $\left(100^{\circ} \mathrm{C}\right)$ for $3-6 \mathrm{~h}$. 2: $\left(\mathrm{C}_{6} \mathrm{H}_{5}\right)_{4} \mathrm{SbOAc}, \mathrm{mp}$ 135- $136^{\circ} \mathrm{C}$ (lit. $\left.{ }^{37)} 129-131{ }^{\circ} \mathrm{C}\right), \quad \mathbf{1 0}:\left(4-\mathrm{CH}_{3} \mathrm{C}_{6} \mathrm{H}_{4}\right)_{4} \mathrm{SbOAc}, \mathrm{mp}$ $160-163^{\circ} \mathrm{C}$ (lit. $\left.{ }^{38)} 157-158.1^{\circ} \mathrm{C}\right), \quad 11:\left(4-\mathrm{ClC}_{6} \mathrm{H}_{4}\right)_{4} \mathrm{SbOAc}, \mathrm{mp}$ $184-187^{\circ} \mathrm{C}$.

35) Lu W., Xi C., Tetrahedron Lett., 49, 4011-4015 (2008).

36) Lockhart T. P., J. Am. Chem. Soc., 105, 1940-1946 (1983).

37) Goel R. G., Can. J. Chem., 47, 4607-4612 (1969).

38) Affsprung H. E., Gainer A. B., Anal. Chim. Acta, 27, 578-584 (1962). 